\title{
Role of Interreligious and Intercaste Marriages in Achievement of the Constitutional Goal of Unity and Integrity in India
}

\author{
Deepti Khubalkar \\ \{deeptikhubalkar@gmail.com\} \\ Symbiosis International (Deemed University) - Nagpur - Maharashtra State, India
}

\begin{abstract}
Since ages, the Indian social system is governed on the basis of caste. According to the old scripts such as Manusmriti, work was divided amongst the people in Indian ancient society on the basis of caste, in which some of the communities were treated as lower caste because of the nature of the work distributed to them under the social arrangement. However, the system proved fatal in due course and resulted in the gross violation of human rights of backward caste. After independence, the Constitution of India, in 1950 provided special provisions in favor of backward category in educational institutions and public employment. In absence of clarity and definite criteria of deciding a caste as a backward category, various communities and caste claiming to be backward in nature started demanding reservations and benefits. From time to time, Government of India included these castes in schedule caste list and declared reservations by suitable amendments in the respective laws. Recently, in India, there is a great demand by the open category for removal of reservation on the basis of caste in the educational field in order to save merit. This scenario has created a new division of society into the open category and reserved category. Certain unpleasant incidences are alarming these days. And it is very clear that even after 72 years of Independence, the Indian legal system has failed to solve the issue of casteism in India. In this background, the researcher has tried to throw light on the role of Intercaste and Interreligious marriages in removing the caste system and bringing unity and integrity amongst the personages which is one of the Constitutional goal enshrined in the preamble of the Constitution.
\end{abstract}

Keywords: Intercaste marriages; caste system; discrimination; Constitution of India; right to equality; unity and integrity of the country

\section{Introduction}

Sixty-nine years ago, "we the people of India" set for themselves the goal of achieving amongst other things unity and integrity of India. The goal assumed importance on the background of bitter experiences of frequent attacks and war and consequent slavery through which India had to pass because of differences amongst people. Therefore, the visionaries of free India had developed a dream of One India. Setting such a goal for themselves was a step taken in the direction of that dream. In 1950, when the Indian Constitution came into force, there were various religious, linguistic, caste and cultural groups in India. Partition of India with Pakistan resulted in communal violence and many communities in the country started feeling insecure. During British regiment, religious differences were nurtured which further 
resulted in communal differences. There was no uniformity in the application of personal laws. Communities were allowed to be governed by their personal laws relating to marriage, adoption, divorce etc. These laws were based on religious texts. In this background, the drafting committee constituted by the Indian government with the purpose of framing the constitution of India was very much worried about the unity and integrity of the country amidst various religious groups. To bring communal harmony and unity amongst the people of India, Government adopted the principle of secularism in its governance i.e. non-interference into the matter of any religion.

The intended goals of the Constitution which our forefathers wanted to achieve, were thus declared in the form of the preamble which, along with other values like Socialism, Secularism, also declares Equality, Justice and Fraternity as an objective in the preamble to assure the dignity of individuals and the unity and integrity of the country. The expression "Union of States" emphasizes the unity of the country as a whole; the constituent units have no liberty to secede from it. There are, however, other provisions which are against the fraternity, such as the division of States on linguistic lines and provisions relating to language.

In Modern India, the traditional caste system is an additional menace to the above division of Indian subcontinent. Muslim's rights are a matter of concern amongst highly populated Hindu community at Gujrat. Similarly, the Hindu community does not feel safe in places such as Kashmir and in Kerala. Though the caste system is the biggest menace in India, the term is not defined anywhere. Constitution of India, guarantees right to equality to all persons within the territory of India and prohibits discrimination on the basis of caste, religion, race etc. However, in absence of any specific definition of these terms including caste and religion, the concept is misused and misinterpreted in favor of certain communities. Supreme Court of India has tried to clarify this term in its numerous judgements. It is said that caste system has its inception in Manusmriti, and is normally connected with the birth of a person in a particular caste such as a person can call himself a Hindu if has taken birth in Hindu family or brought up by Hindu parents. These rules are a matter of long practice in India.

Since there has been no specific criterion for determining someone's caste, the decision of caste in India has been done solely on the basis of birth. Although the Constitution of India gives liberty of faith and religion to be professed, practiced and propagated, whenever any person goes for conversion, the society depicts a hostile attitude to this idea which often results in violence and boycott from society. In the era of globalization, where everything is transformed to intermingle with each other, there is a huge failure in removing the problem of the caste system in India and has, therefore, become the biggest hurdle in its progress. Constitution of India, through Art 44 (Part IV - Directive Principles of State Policy), imposes a duty upon the state to secure a Uniform Civil Code for all the citizens of India irrespective of their caste and religion.

India is a secular country and every community has the freedom to practice its own religion. In the absence of implementation of the Uniform Civil Code, marriages are governed by personal laws. India has a multiplicity of family laws most of which do not recognize intercaste marriages. Muslim law, which is still uncodified, provides that marriage with a nonMuslim is null and void. Even children begotten out of such marriages are considered as illegitimate hence deprived of many property and family rights. The Christian and Parsi laws, both prohibit intercaste marriages. The Christian Marriage Act provides that marriages can be performed between Indian Christian and non-Indian Christians. But it seems that under the Act a marriage between a Christian and a non-Christian is not valid if it is permitted by the personal law of parties. 
Under the Parsi Law, marriage between non-Parsi and Parsi is invalid. Whereas, marriage between such persons is valid in Special Marriage Act 1954 which provides for a secular method of marriage and religion is not a criterion for the validity of any marriage contrary to the Hindu, Christian and Muslim marriage methods. The basic purpose of passing this law i.e. Special Marriage Act 1954 is to ensure validity of a marriage between persons of different religions and caste. Thus in absence of Uniform Civil Code, Special Marriage Act 1954 is a ray of hope in order to bring uniformity at least in matrimonial matters. The religion oriented personal laws of our country are all outdated and encourage casteism. These personal laws are not only in contrast with the letter and spirit of Caste Disabilities Removal Act 1850, but also contrary to the spirit enshrined in the Preamble of our Constitution and to the provisions of Right to equality, right to personal liberty and right to life and right to religion under Art. 14, Art 15, Art 19, Art.21 and Art.25.

Previously caste system was totally different from the present prevalent caste structure of the society. The previous practice of caste system is almost vanished now. Previously caste was usually associated with the occupation; however present situation is totally contrary to it, and has restricted the caste practice on few things only such as performance of marriages.

\section{Problem of Caste system in India}

Throughout the world, India is the only country in the continent which is divided on the basis of caste and infected with caste system. Multiplicity of caste and religion itself is not a problem. However, the bad side of this system is that, it has become a hurdle in achieving the constitutional goal of unity and integrity of the country. Political leaders are encouraging these differences for their vote bank and other benefits. Further, compulsion of marital laws with respect to marriage within religion for the validity of marriage has become a stumbling block to the social integrity. It has become a mindset of people to love only those who are belonging to their caste. Such kind of mindset is totally against the values which we want to achieve through the Constitutional goal. As a result, at the time of independence, there was a great demand for reservations for certain communities on the basis of caste.

To remove social injustice from the society, certain fundamental rights were included in the constitution in favor of reservations under Art. 15 and 16 for the limited time. Gradually, this time period of quota in various sectors is extended by the Government. Certain more castes were added to the list of castes which were entitled to the benefit. In the year 1992, it crossed even 50\% during the governance of Janta Dal Party through Mandal Commission. Such policy of the Government, affected the educational and economic interest of those who were not entitled to reservation (Open Category). Many students from open category agitated against the policy of relaxation in marks for reserved category and comprising with merit for qualifying exam and getting admissions to professional institutions by self-immolating themselves. Recently few more reservations are declared on the basis of caste in few of the states in India which has crossed even $60 \%$ of reservation of seats.

Ayodhya dispute of 1993-94 is the glaring example to show how the politicians are using the caste system for filling their vote bank by dividing people. In the landmark judgement of Ayodhya dispute Supreme Court observed that "the dispute relating to the structure in Ayodhya led to the communal tension and violence resulting in loss of many lives and destruction of property throughout the country." With a view to maintain communal harmony 
and fraternity in India the Union Government issued an Ordinance acquiring certain areas at Ayodhya which subsequently become an Act.

The issue of reservation is an added salt to the injury which is leading the nation towards communal war. The open category people feel injustice because of reservation policy of Union and state Government. Thus, again the policy of reservation is dividing the modern Indian society in three classes: higher class, backward class / schedule castes and other backward classes by creating tension over reservation. Mandal case is a good example to show how the politicians have deliberately flouted the constitutional provisions. The reservation policy in Mandal commission resulted into big loss of persons and property which further created a division of people into open category and reserved category and gave new colors to caste system in India.

Thus caste system is directly or indirectly splitting Indians. The existence of casteism, communal hatred, communal disharmony among Indians, is a hindrance, an obstacle in achieving the goal of unity, integrity of India which is proclaimed in the constitutional preamble. Thus because of non-achievement of this goal progress of country is stalled. We claim to achieve the status of being Super Power by 2020 but we are wasting our energy in fighting with each other over the issue of casteism and reservation. It seems that only the intercaste and interreligious marriages can remove the menace of caste system in India. The existing caste system does not encourage inter-caste or interreligious marriage. On the contrary, there are various legal provisions recognizing inter-caste / inter-religious marriage under Special Marriage Act 1954. Moreover, it is a Constitutional right to marry anyone he or she likes to marry as interpreted by courts in various cases under Art. 21 of the Indian Constitution. Despite that if such marriages are not acceptable to society it will lead to divorce and unhappy ending of the marriage. Such system not only affects the couple but adversely leads to division of the country.

India is one of the multi religious nation in the world. Luckily it is a secular country instead of religious country. Other than Hindu there are many religious groups who also follow caste system. Though the Indian Constitution has formally rejected the unequal treatment on the basis of caste and religion, caste system is a curse for India especially in rural area. Since British period religion based society is proved harmful to nation in one or other way. Policy of the British to 'divide and rule' resulted into partition of India, on religious basis. Thereafter series of demands of separate states on religion basis like demand of Khalistan in Punjab, and Bodo land in Assam have weakened the unity and integrity of the country. Reports of violence amongst the community shows that all governmental policies to evade caste based inequality is proved unsuccessful in achieving its goal. The modern India is thus facing lot of financial loss on security and on maintenance of peace and order. Values enshrined in our Constitution of rule of law and equality, fraternity, secularism, instead of becoming a part of our daily lives, is falling prey to communal violence.

While all efforts seem to be failing, the pronouncement from none else than topmost legal institution of India; the Supreme Court , in the case of Lata Singh v. State of UP has come as a refreshing breeze. The judgment has brought a ray of hope. It has given us the direction to think in new ways. Supreme court in this case suggested that the intercaste society solidly integrated in more ways than one. Recently, in response to a case of police harassment to an intercaste married couple, Hon'ble High Court of Chennai observed that the intercaste marriages are necessary to uproot caste system from India.

The Court observed thus:

"In fact many thinkers believe that inter-caste marriage is the only panacea to root out the evil of caste system. These are days where the younger generation is slowly moving out of the 
ill-effects of caste system and that is the reason for a lot of inter-caste marriages. These changes must be accepted by the elders and this change is in fact good for the society in rooting out the caste system."

\section{Conclusion and Suggestions}

Researcher opines that court has rightly observed the problem of caste system in India and its solution. Only love among the community can achieve the goal of unity and integrity of our Constitutional goal. Court has very rightly observed that such marriages should be encouraged by giving proper support and incentives. Since ages, the Indian social system is governed on the basis of caste. According to the old scripts such as Manusmriti, work was divided amongst the people in Indian ancient society on the basis of caste, in which some of the communities were treated as lower caste because of the nature of the work distributed to them under the social arrangement. However, the system proved fatal in due course and resulted in the gross violation of human rights of backward caste. After independence, the Constitution of India, in 1950 provided special provisions in favour of backward category in educational institutions and public employment. In absence of clarity and definite criteria of deciding a caste as a backward category, various communities and caste claiming to be backward in nature started demanding reservations and benefits. From time to time, Government of India included these castes in schedule caste list and declared reservations by suitable amendments in the respective laws.

Recently, in India, there is a great demand by the open category for removal of reservation on the basis of caste in the educational field in order to save merit. This scenario has created a new division of society into the open category and reserved category. Certain unpleasant incidences are alarming these days. And it is very clear that even after 72 years of Independence, the Indian legal system has failed to solve the issue of casteism in India. With the everyday development on technological front, the whole world is fast becoming a global village in true sense of the term. With the advent of internet technology which has now permeated in our day to day life, the process of intermingling of people at international level has started long back. India cannot afford to remain aloof from this global phenomenon.

If at all India desires development along with international community, then what is happening at global level i.e. intermingling of people of various countries, races, cultures, creed etc. must also affect what should happen at country level for development. In other words, love begets love. The people of India who belong to different castes and cultures are necessarily required to forget their differences and become united. The importance of unity and integrity as well as secularism is specifically incorporated in the preamble of our Constitution. Intercaste and interreligion marriages can be one of the most effective tool to eradicate these differences.

\section{References}

[1] Basu, Durga Das, Shorter Constitution of India, 11th edition, New Delhi, Prentice Hall of India Pvt.Ltd.1994

[2] Diwan Paras, Law of Marriage and Divorce, Nagpur : Wadhwa and Co.,1998

[3] Jain, M.P., Outline of Indian Legal History, 4th editing, New Delhi, Jawaharlal Nehru Memorial Foundation, 1994 
[4] Pant P.C., the Law of Marriage and Divorce and other Matrimonial Disputes, Allahabad: Orient Publishing Co.,1996

[5] Swami Agnivesh, Thampu Valson," Casteless Society and Indian of our Dreams." 19th Jul2007

[6] http;//www.swamiagnivesh.com/casteless.htm

[7] https://www.livelaw.in/news-updates/inter-caste-marriages-root-out-the-caste-system-145781

[8] http://www.articeolineddirectory.com/article30535,19july 2007

[9] http://www.Kantipuronline.com/Kilnews.php\&nid_intercaste_marriage 